\title{
A COMPARATIVE STUDY ON THE INVESTMENT VALUE OF RESIDENTIAL PROPERTY AND STOCKS
}

\author{
Bing SUN, Hongyu LIU and Siqi ZHENG \\ Institute of Real Estate Studies, Tsinghua University, Beijing, China, 100084 \\ E-mail: liuhy@tsinghua.edu.cn
}

Received 6 February 2004; accepted 14 June 2004

\begin{abstract}
As real estate, residential property comprises not only the value of utilization, but also the value of investment, which is somewhat different from that of securities such as stocks and bonds. In this paper, the investment value of newly-built residences and stocks are compared and analyzed theoretically and empirically. Firstly, the paper summarizes the diversity of costs, risks, and benefits of these two investments. Secondly, by quoting the quarterly price/rent indices on the housing market and that at the stock exchange in Shanghai, the paper explores the variances of these two investments with respect to their risk-return characteristics from 1993 to 2003. Thirdly, the paper discusses the correlations between residential property price/rent index, property/general stock price index, and Consumer Price Index (CPI). Finally, by utilizing the Capital Asset Pricing Model (CAPM), the systematic and the unsystematic risks of these investments are segregated and compared with each other, based on a series of assumptions. The result suggests, on a quarterly basis, that residential property investment produces a higher risk-adjusted return than that of general stock and property stock investment. Because of a weak/negative correlation between residential property and stock returns, residential property is an ideal candidate to be included into the stock investment portfolio. Moreover, residential property and property stock can be used as effective hedges against inflation.
\end{abstract}

KEYWORDS: Residential property; Stock; Benefit; Risk; Correlation

\section{INTRODUCTION}

The stock market is one of the major domestic investment fields at the present stage. While it emerged around 1990 and 1991, there were only 13 listed companies with fewer transaction volume and fund amount. However, it has grown rapidly within the following several years. And by the end of 2003, the number of listed company in the domestic stock market has reached 1287, with the market value of RMB4245.771 billion. In 2003, the total transaction volume on the domestic stock market is RMB3211.513 billion, including RMB2082.4 billion for the Shanghai Exchange, and RMB1129.113 billion for the Shenzhen Exchange, respectively. As the stock market is getting more developed, it has attracted more and more people to invest. Till 2003, the number of investor accounts in the domestic stock market was 70.25 million, which $99.9 \%$ of them were individual accounts.

In $1980 \mathrm{~s}$, the Chinese government started to reform its traditional housing system, i.e., shifting from a truck system to a monetary system. It has been repeatedly demonstrated that the monetarization of the house distribution system and the commercialization of the house exchange system contributed greatly to the development of the housing market, which led the citizen households to become the mainstay demanders on the housing market. The annual sales revenue on the housing market in 2003 is RMB 63.0385 billion, $92 \%$ of which 
comes from individual consumption. Residential property has become the most important household asset. Fluctuation in asset value will significantly influence the quality of the household assets. In recent years, with the skyrocketing of house prices in the major Chinese cities, namely Beijing, Shanghai, Shenzhen, and Hangzhou, the investment value of a residential property has gained more attentions. As real estate, residential property possesses not only the value of utilization but also the value of investment, which is somewhat different from that of the securities such as stocks and bonds.

The investment channels of residential property can be divided into direct investment and indirect investment (Liu Hongyu, 2002). Direct investment includes residential development and purchase. The former mainly focuses on profits from real estate development. Meanwhile the latter, viewed as long-term investment, prefers to make a profit on the aspects of rent, capital gain, and its consumption value. However, indirect investment consists of the purchase of stocks and bonds issued by real estate developers and investors, and funds injected to the Real Estate Investment Trust (REITs) and Mortgage-backed Securities (MBS or CMBS). The paper is merely focusing on the investment value of the residential property purchase on the primary housing market.

Since the characteristics of residential property are obviously different from those of the stocks, the costs, risks, and returns of these two investments are also showing distinctive features. In this paper, the investment values of the residential property and stocks are compared from both theoretical and empirical standpoints. The empirical comparisons will include cash return and other benefits, either tangible or intangible.

The paper will be unfolded by the following structure: Section 2 will summarize the differences of costs, risks, and benefits of the investment of residential property and stocks, and Section 3 will give an introduction on the methodology of this paper. Section 4 will provide an empirical study on the risk and return characteristics of these two investments, and discuss the correlation between residential property, property stock, general stock, and Consumer Price Index (CPI). Section 5 will draw some conclusions, both theoretically and empirically, in which the limitation of this paper will also be mentioned.

\section{THE INVESTMENT VALUE OF RESIDENTIAL PROPERTY AND STOCKS}

The paper will discuss the investment costs, risks, and benefits of residential property and stocks theoretically in this section, with a review on the relevant studies on the same aspect previously. Compared with stocks, the distinction of residential property mainly focuses on tangibility, immovability, adjustability, heterogeneity and economic life extensibility. The complicated nature diversifies the investment value of residential properties.

\subsection{Investment costs}

Unlike stocks, the costs of residential investment comprises not only the asset price and transaction expenses, but also the search cost and holding cost occurred in the process of trading and leasing. Due to the heterogeneity of residential property, asymmetric and imperfect information on the housing market, more search cost by means of time, energy, and fund, would be incurred, in order to obtain specific information such as price and quality of a certain residential property. Such information will help the residential investors find the ideal target after making comprehensive weighing. Moreover, the investors of the residential property will also have to pay a series of expenses such as property maintenance fee and management fee. As for the leased property, an investor has to spend additional time and energy to find and hold the ideal lessees or to engage the real estate brokers if necessary. The 
injection of holding cost will significantly influence the rental income and capital gain of residential property in the future. On the other hand, the stock investor has access of information on the stock market to minimize the search cost, and stock investment is the mere exchange between cash account and securities account, with no holding cost as discussed above.

\subsection{Investment risks}

It is generally accepted that the risk of stock investment is $\beta$ risk, and the unsystematic risk of the stock investment can be minimized through asset portfolio. Therefore, stock pricing is theoretically based on the systematic risk it bears. However, the investment risk of residential property is not limited to $\beta$ risk and might include interest risk, liquidity risk, indivisibility risk, operation risk, contingent risk and etc.

The interest risk of residential investment mainly includes the impacts on the following two aspects, i.e., on the residential property value and on the fund utilization cost. An increase in interest rate will diminish the demand in the housing market and lead to a devaluation of residential property. Moreover, an increase in interest rate will obviously increase the fund utilization cost. As an immovable real asset, the liquidity of a residential property is poor. It compels the investor to face higher liquidity risk, i.e., the residential property may not be exchanged to the equivalent cash asset in short order unless it was sold at a discount. Since the general transaction unit of residential property is suite, which cannot be further broken down, this will take a large sum of fund and bring up indivisible risk. The operation risk represents the potential loss occurred from the un-matched market demand, such as the deficiency on function orientation, facility application, and property management. Contingent risk indicates the uncertainty of return attributed to the natural calamity, such as fire and earthquake. Although the investor can shift the contingent risk to insurance company or lessees, certain corresponding cost has to be paid, i.e., a higher investment cost (insurance fee) or a lower rental income.

\subsection{Investment benefits}

(1) The risk-return ratio of residential property investment is less than that of stock investment.

In spite of using different methods to adjust the rate of the investment return to the level of risk, some overseas studies have drawn similar conclusions that direct property investment has a better risk-adjusted return than that of stocks. Such studies were mainly conducted on the property and stock markets in the U.S. (Webb and Sirmans, 1980; Irwin and Landa, 1987; Webb, 1990; Goetzmann, 1993). Such conclusions were also drawn in relevant studies in the U.K. (Howells and Rydin, 1990), Canada and Switzerland (Hoesli and Anderson, 1991).

(2) Including residential property into the stock portfolio can reduce the investment risk.

Generally speaking, stocks and houses enjoy the downward order of the risk hierarchy, and the correlation between the returns from property and stocks is weak and even negative, which enables the property, such as residential property, to act as an important element in diversifying the risks of a mixed-asset portfolio. Most of such studies were conducted on the markets in the U.S. (Ibbotson and Siegel, 1984; Irwin and Landa, 1987; Webb, 1990). Similar results were also reported in the U.K., Canada and Switzerland.

In 2002, a paper, named "Hedging Housing Risk", written by Peter Englund, Min Hwang and John M.Quigley, analyzed the composition of a household investment portfolio, including residential property, common stocks, stocks in real-estate holding companies, bonds, and tbills. The conclusion is that, for a short holding period, the efficient portfolio essentially contains no residential property. In the mean- 
time, for a longer period, low-risk portfolios contain 15-50 percent of residential property (Peter Englund, Min Hwang and John M.Quigley, 2002).

(3) Residential property is an efficient hedge against inflation.

From the theoretical standpoint, residential property can experience capital appreciation on an inflationary market, because inflation will cause the rebuilding costs to increase, and then result in a higher residential property value. On the other hand, even during the deflation period, the consumption value of residential property will not be decreased. Thus, the residential property can be used to hedge against inflation. Empirically, many quantitative results provide sufficient evidence that residential investment return is significantly correlated to inflation (David Hortzell, John S.Hekman, and Mike E.Miles, 1987; Robert R. Grauer and Nils H. Hakanssor 1995; Bond, Seiler, 1998; Quan, Titman, 1999). Because of such inflation hedging effect, residential property is regarded as a favorable investment choice for risk-averse investors, such as pension funds and insurance companies. However, some other researchers have cast doubts upon this conclusion. Some of them even achieved opposite empirical study results. Fletcher (1995) pointed out that the conclusion of residential property with inflation-hedging ability totally relied on the methodology and the kind of time series data the researchers selected. Steven and Murray (1999), by causality model, found out that the fluctuation of house price is one of the key factors leading to inflation.

(4) The potential return for residential property investment is considerable.

The stocks issued by one listed company are highly homogeneous, and the performance of stock investment is mainly dependent on three factors: the stock market condition, the development status of specific industries and the financial situation of the listed company. Thus an individual investor generally cannot affect the stock value.

Nevertheless the residential property pro- vides investors the opportunities to work on its value. The heterogeneity, adjustability, and economic-life extensibility of the residential property decide that, two different units in the same building may create distinguishable returns. In the housing market, two identical units do not exist. To some extent, the investment returns to be realized and enhanced, are determined by whether the property can meet the demanders' requirements, or simply outperform that. The demanders on the secondary housing market comprise renters and purchasers. Those investors, who orient the property function in accordance with the market, provide high value-added products and services, not only can achieve an above-average return but also realize the relevant long-term investment returns through extending the economic-life of the residential property. Apparently, it is indicated that the potential benefits of residential property investment are larger than that of stocks, and can be realized by the investors' own effort.

\section{METHODOLOGY}

Returns from investment are normally calculated on an annual basis. Risk is defined as the standard deviation of return over time. Risk of an investment is higher if the standard deviation of its return is larger than that of others, and vice versa. The formula to calculate risk is as Equation (1), where $\bar{R}$ indicates the average rate of return from the investment.

$$
\sigma=\sqrt{\sum_{i=1}^{n}\left(R_{i}-\bar{R}\right)^{2} / n}
$$

Modern portfolio theory provides the theoretical underpinning for this study on asset investment risk segregation. This theory starts with the pioneering work of Markowitz on riskreturn optimization five decades ago. In order to construct a set of optimal portfolios, the Markowitz Model requires complex calcula- 
tions, which only deal with the efficient portfolios, not individual assets. Sharpe proposed the Capital Asset Pricing Model (CAPM) and derived the Security Market Line on the basis of a single-index model. The theory is now frequently applied on discussions of the relationship between risk and return in different investment portfolios and the issue of pricing for individual assets. The equation of the SML states:

$$
\begin{aligned}
& R_{i}=R_{f}+\beta_{i}\left(R_{m}-R_{f}\right) \\
& \beta_{i}=\rho_{i m} \times \frac{\sigma_{i}}{\sigma_{m}}
\end{aligned}
$$

where: $\beta_{i}=$ Beta coefficient of asset $i ; \rho_{i m}=$ Correlation between asset $i$ and market portfolio; $\sigma_{m}=$ Standard deviation of market portfolio; $\sigma_{i}=$ Standard deviation of asset $i ; R_{i}=$ Expected return on asset $i ; R_{f}=$ Risk-free rate of interest;

The coefficient $b$ measures the systematic risk of an individual asset. It is defined as the covariance of its return in the market, divided by the variance of the market return. The systematic risk of an asset is $b$ multiplied by the risk of a hypothetic market portfolio. The systematic risk is not diversifiable. Another portion of the total risk, i.e. unsystematic risk, can be diversified by optimal portfolios. Theoretically speaking, investment returns depend on the systematic risk. On the other hand, the unsystematic risk would not be rewarded.

Equation (2) states that the expected return on an asset or asset portfolio equals the risk-free interest rate plus the product of the unit return of market risk (including systematic risk only) and the systematic risk in the asset or asset portfolio. Although many assumptions of CAPM are obviously at odds with reality, for instance all the investors are evaders from risk and the unsystematic risk has been completely diversified, many studies have demonstrated that this theory, as simplistic as it is, satisfies the demand of approximate research on the relationships between risk and return.

\section{EMPIRICAL STUDIES}

The empirical study in this paper focuses on the newly-built residential property in Shanghai housing market and the stocks listed in Shanghai Exchange. The analysis in this section will be divided into three parts. The first is to explore the variances of these two investments with respect to their risk-return characteristics. Secondly, the correlations between residential property price/rent index, property/general stock price index, and Customer Price Index (CPI) are discussed. Finally, based on a series of assumptions, the systematic and unsystematic risk of these asset investments are segregated and compared with each other.

In overseas researches, two kinds of data are generally used to calculate the investment return of a residential property. They are the appraised value of the property and the price of residential property backed securities. Till now, there are no such financial products as REITs and MBS in the Chinese security market. To measure returns based on appraisal value, have two shortcomings (Roger G. Ibbotson, Laurence B. Siegel, 1984). One is the inaccuracy problem stemming from traditional appraisal methods. The other is the disaccord between the actual sale price and the appraisal value because of bad liquidity and imperfect information in the housing market. In order to avoid such shortcomings of the data, this paper uses the price/rent indices to scale the property investment returns, which are deduced from the practical sale price/rent of relative homogeneous residential properties.

\subsection{Data source and process}

The quarterly data of residential property price/rent index in this paper are derived from DTZ Shanghai's real estate periodical of indices on office and residential property in Mainland China. The range of the time series is from the third quarter of 1993 to the final quarter of 2003. The calculation of these indices is 
based on the real price/rent of the practical property trade-off, which excludes management fees, property tax, and maintenance expenses. The sample residential properties are of relative homogeneity, with basic facilities, under similar usage, and located in the central living district.

To calculate the gains from residential property investment, the paper took both capital gain and rental income into account, which can be formularized as the following Equation (4):

$$
R O R_{i}=\frac{P I_{i}-P I_{i-1}}{P I_{i-1}}+\frac{R_{i}}{P_{i-1}}
$$

where: $R O R_{i}=$ The rate of return from residential property investment at time $i ; P I_{i}=$ The residential property's price index at time $i ; R_{i}=$ the rental income at time $i ; P_{i-1}=$ The market price of the residential property at time $i-1$.

In calculating $\frac{R_{i}}{P_{i-1}}$, it is supposed that the rental price ratio in the fourth quarter of 2002 is $0.75 \%{ }^{1}$, based on deduction of the ratios for other periods.

The general stock price index adopted in this paper is the Shanghai Exchange General Index, which is based on all the listed stocks (including A share and B share) and therefore can represent the price trend and fluctuations at a macroscopic level.

The property stock price index used in this paper is also from the Shanghai Exchange, which is the relevant index of property stocks listed at the Shanghai Exchange, which consists of 20 sample stocks, and such price index can represent the status quo of the whole industry. For details, please refer to Exhibit 1.

Since it is difficult to collect relevant data of dividends, and capital gain is the predominant return on the Chinese security market, the paper ignores negligible dividends, and calculates the rate of return from stock investment only based on the relative movements of two consecutive price indices.

The deposit rate adopted in this paper is the statutory 3-month time deposit rate issued by the People Bank of China. The paper introduces the quarterly Consumer Price Index (CPI) in Shanghai as the proxy for local inflation level.

\subsection{Risk and return on a quarterly basis}

Figure 1 is the graphical representation of the return and risk of various assets on a quarterly basis, including residential property, property stock, general stock and savings. Exhibit 2 presents a summary of the results on the comparisons of the aforementioned items on a quarterly basis.

Merely in terms of capital gain, both general stock and property stock investment fared better than residential property investment. However, higher stock returns face higher risk. The standard deviation divided by the average quarterly return gives the risk-return ratio, indicating the risk that investors have to bear for each unit of return. The risk-return ratio for both general stock and property stock investment are higher than that of residential

Exhibit 1. The Samples for Property Stock index calculation at Shanghai Exchange

\begin{tabular}{llll}
\hline Xin Kai (600167) & Tian Fang (600322) & Tian Hong (600376) & Jin Di (600383) \\
Xi Xia (600533) & ST Xing Ye (600603) & Hai Niao (600634) & Xin Huangou (600638) \\
Zhong Yuan (600641) & Wai Gaoqiao (600648) & Lu Jiazui (600663) & Zhonghua (600675) \\
Tian Chuang (600791) & No. Pharm. (600833) & Jin Qiao B (900911) & Wai Gao B (900912) \\
Dong Hua (600393) & Pudong Jin Qiao (600639) & Zhu Jiang (600684) & Lu Jiazui (900932) \\
\hline
\end{tabular}

1 Data source: DTZ quarterly research report on Shanghai housing market (the 4th quarter, 2002). 


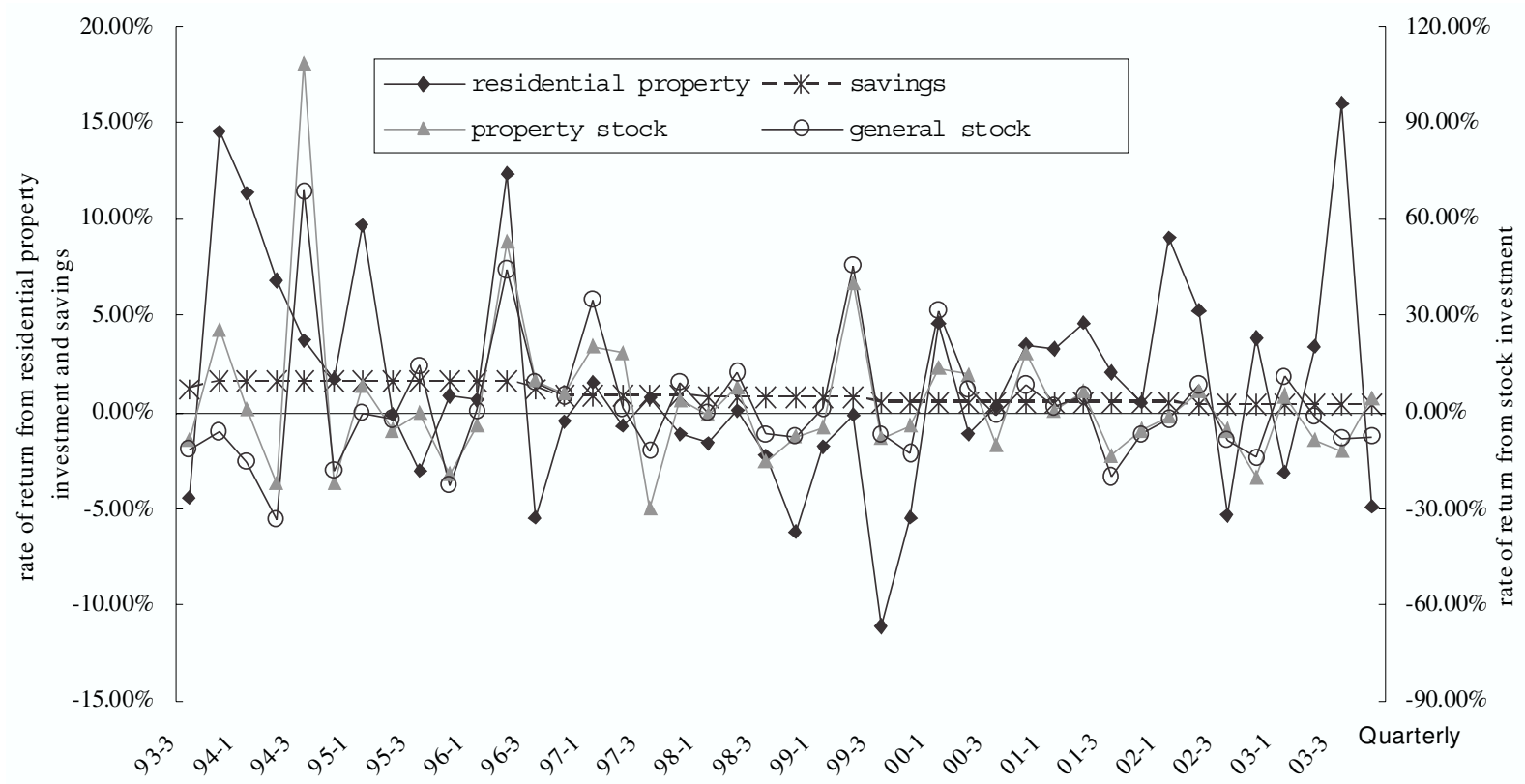

Figure 1. Rate of Return for Each Asset on a Quarterly Basis (the third quarter, 1993 the fourth quarter, 2003)

property investment. General stock, in particular, has the highest risk-return ratio of 9.04. This suggests that the investors of general stock are subject to $9.04 \%$ risk for each $1 \%$ of return. Moreover, the return of the saving investment is nearly a half of that of residential property investment, but the associated risk is significantly lower.

By means of total return, since the calculation of stock investment return in this paper did not include dividend, the property stock and general stock enjoy the same result. However, the return of residential property changed due to rentals being taken into account. The rate of return rises to $1.47 \%$ and risk-return ratio attenuates to 3.91. Therefore, for each unit of return, the risk of residential property investment has been about $50 \%$ and $40 \%$ of that of property stock and general stock, respectively.

Exhibit 2. Return and Risk of Each Asset on a Quarterly Basis (the third quarter, 1993 the fourth quarter, 2003)

\begin{tabular}{lllll}
\hline & & Rate of Return & \multicolumn{2}{l}{ Standard Deviation } \\
& & (2) & $\begin{array}{l}\text { Coefficient of Variance } \\
\text { (2)/(1) }\end{array}$ \\
\hline Residential & Capital Gains Only & 0.2453 & 5.7111 & 23.2821 \\
Property & Rental Only & 1.2268 & 0.4318 & 0.3520 \\
& Total Return & 1.4721 & 5.7609 & 3.9134 \\
\hline Property Stock & & 3.2043 & 23.2164 & 7.2454 \\
General Stock & & 2.1462 & 19.4064 & 9.0422 \\
Savings & 0.8946 & 0.5001 & 0.5590 \\
\hline
\end{tabular}




\subsection{Correlations between the Assets and CPI}

The correlation analysis is to search for the relationship between the movements of two or more numerical variables. Correlation does not mean a causality relationship existing between the variables. If the correlation coefficient equals one, it implies that these two variables have a surely linear relationship with each other. If the correlation coefficient is below one, there is no certain relationship existing, but a specific linear relationship with the best possibility can be set up. By SPSS software, the paper conducts a Pearson correlation coefficient calculation on the quarterly return of each asset investment. The results are showed in Exhibit 3.

On a quarterly basis, capital gain and rental income of residential property have weak and negative correlations with property stock and general stock respectively, rendering residential property a good candidate to be included in mixed-asset portfolios for riskdiversification purpose. Moreover, the significant positive correlation between residential property and inflation suggests that, over the studied period, residential property might be a good hedge against inflation. The property stocks also enjoy the same inflation hedging ability.

\subsection{Comparative segregation of risk}

So far, standard deviation of returns has been treated as the proxy for risk. This is, however, only a measure of dispersion of returns in excess of the average within a period of time.

Exhibit 3. Correlation Coefficients between these Assets (the third quarter, 1993 the fourth quarter, 2003)

\begin{tabular}{|c|c|c|c|c|c|}
\hline Correlation Coefficient & $\begin{array}{l}\text { Rent Index of } \\
\text { Residential Property }\end{array}$ & $\begin{array}{l}\text { Price Index of } \\
\text { Residential Property }\end{array}$ & $\begin{array}{l}\text { Property } \\
\text { Stock }\end{array}$ & $\begin{array}{l}\text { General } \\
\text { Stock }\end{array}$ & CPI \\
\hline $\begin{array}{l}\text { Rent Index of } \\
\text { Residential Property }\end{array}$ & 1.000 & & & & \\
\hline $\begin{array}{l}\text { Price Index of } \\
\text { Residential Property }\end{array}$ & $0.628 * *$ & 1.000 & & & \\
\hline Property Stock & 0.064 & 0.200 & 1.000 & & \\
\hline General Stock & $-0.363 *$ & $-0.431 * *$ & $0.649 * *$ & 1.000 & \\
\hline CPI & $0.358 *$ & $0.514 * *$ & $0.380 *$ & -0.238 & 1.000 \\
\hline
\end{tabular}

* Significance at 0.05level (two-tailed)

** Significance at 0.01 level (two-tailed)

Exhibit 4. Risks Segregation of Residential Property and Stock Investment

\begin{tabular}{lllll}
\hline & \multicolumn{2}{l}{ Residential Property } & $\begin{array}{l}\text { Property } \\
\text { Stock }\end{array}$ & $\begin{array}{l}\text { General Stock } \\
\text { (Market Portfolio) }\end{array}$ \\
\cline { 2 - 5 } & Rent operation & Capital gain & & 2.1462 \\
\hline Avg. Return & 1.2268 & 0.2453 & 3.2043 & 19.4064 \\
Standard Deviation & 0.4318 & 5.7111 & 23.2164 & 1.0000 \\
$\beta$ & -0.0081 & -0.1268 & 0.7764 & 1.0000 \\
\hline Naïve Risk & 0.0223 & 0.2943 & 1.1963 & 19.4064 \\
\hline Systematic risk & & & & 0.0000 \\
Unsystematic risk & 0.1567 & 2.4615 & 15.0674 & $100.00 \%$ \\
Percentage of systematic risk & 0.2751 & 3.2496 & 8.1490 & $0.00 \%$ \\
Percentage of unsystematic risk & $36.30 \%$ & $43.10 \%$ & $64.90 \%$ & $35.10 \%$ \\
\hline
\end{tabular}


This measure of dispersion includes both systematic and unsystematic risk elements. The CAPM enables us to estimate the systematic and unsystematic risk of an asset investment by constituting a market including real property, stock, and bonds. However, because of the absence of data, in this paper, the market is represented by the general stock market. The quantitative result here can only provide prima facie evidence on each asset's risk segregation.

The result of segregation was listed in Exhibit 4 . The naïve risk is defined simply as the ratio of the standard deviation of the asset to that of market portfolio. It is a measure of the asset's total risk relative to the market. It is shown that the rental income of residential property carries the least naïve risk. In terms of systematic risk, the same conclusion can be drawn, as the rental income is at the bottom of the systematic risk hierarchy.

\section{CONCLUSION}

(1) Rental income is a dominant source of residential property investment return.

From the data in Exhibit 2, over the studied period, the quarterly rate of return from the rent operation (1.2268\%) is higher than that from capital gain $(0.2453 \%)$, while, for the risk-return ratio, the former $(0.3520)$ is much less than the latter (23.2821). 83 percent of the total income of residential property investment comes from rental operation. Moreover, a stable cash flow from rental income reduces the total risk-return ratio of property investment.

(2) Residential property investment produces higher risk-adjusted return than stock investment.

The Exhibit 2 presents that the rate of investment returns of both general stock $(2.1462 \%)$ and property stock $(3.2043 \%)$, are higher than that of residential property investment $(1.4721 \%)$. However, in terms of risk-return ratio, residential property investment (3.9134) turns out to be less risky than that of stock investment, with 7.2454 for property stock, 9.0422 for general stock. It means that to gain the same unit of return, residential property investment will undertake less uncertainty than stock investment.

(3) There is a weak/negative correlation between residential investment and stock investment.

The correlation coefficients in Exhibit 3 indicate that both returns from capital gain and rent operation represent weak correlations with those from property stock and negative correlations with those from general stock. It implies that the residential investment return is totally independent or even the opposite of stock price movements. Such characteristics of residential investment return determine that it can be deemed as a perfect candidate to be included in stock investment portfolio to diversify its unsystematic risk, and thus stabilize its cash inflow.

(4) Both of Residential property and property stock investment can hedge against inflation.

Also based on the data in Exhibit 3, a conclusion can be drawn that both residential property and stock investment are efficient hedges against inflation, because there are significantly positive correlations between these two assets' investment returns and Consumer Price Index.

(5) The systematic risk percentage of residential investment is less than that of property stock investment.

Based on Exhibit 4, we noticed that more than $50 \%$ of the total risk of residential property investment is unsystematic. The high percentage of unsystematic risk suggests that residential property returns are substantially influenced by the unique factors affecting residential property only. Based on the systematic risk, investors of residential property should be rewarded less than property stock investors.

(6) Residential property has a diversified investment value.

Besides the above-mentioned conclusions drawn from the quantitative study, residential 
property possesses much a more diversified investment value than stock investment. For example, as one of the life necessities, residential properties have consumption value. And in some countries and regions, income tax benefits can be obtained through investing in residential properties. Moreover, possessing residential property can enhance an investor's credit level. As a kind of real asset, which will not be held by many people, residential property can guarantee credit for its owner. Then it creates much more financing and investment opportunities.

Due to the limitation of data source and time series range, part of the data analyzed in this paper cannot find statistical support at the present stage in China. Therefore, we choose the alternatives of using proxies or neglect them at all. All these technical processes will definitely influence the analytical results of this paper. Based on the available data and objective analysis, the paper is just designed for comparing these two investments and exploring the reality as much as possible.

\section{REFERENCES}

Bond, M. T., Seiler, M. J. (1998) Real estate returns and inflation: an added variable approach. Journal of Real Estate Research, 15(3), p. 327338.

Englund, P., Hwang, M., Quigley, J. M. (2002) Hedging housing risk. Journal of Real Estate Finance and Economics, 24(1), p. 167-200.

Fletcher, S. (1995) Commercial real estate investments and returns: a review of the literature using CREF data. Alternative Ideas in Real Estate Investment Research Issues in Real Estate Series, Schwartz and Kapplin (eds.), Dordrecht and Boston: Kluwer Academic.
Goetzmann, W. N. (1993) The single family home in the investment portfolio. Journal of Real Estate Finance and Economics, 6(3), p. 201-222.

Grauer, R. R., Hakansson, N. H. (1995) Gains from diversifying into real estate: three decades of portfolio returns based on the dynamic investment model. Real Estate Economics, 23(2), p. 117-159.

Hoesli, M. E., Anderson, M. S. (1991) Swiss real estate: return, risk, and diversification opportunities. Journal of Property Research, 8, p. 133-145.

Hortzell, D., Hekman, J. S., Miles, M. E. (1987) Real estate returns and inflation. AREUEA Journal, 15(1), p. 617-637.

Howells, P. G. A., Rydin, Y. J. (1990) The case for property investment and the implications of a unitized property market. Land Development Studies, 7, p. 15-30.

Ibbotson, R. G., Siegel, L. B. (1984) Real estate returns: a comparison with other investments. AREUEA Journal, 12(3), p. 219-242.

Irwin, S. H., Landa, D. (1987) Real estate, futures, and gold as portfolio assets. Journal of Portfolio Management, fall, p. 29-34.

Liu, H. Y. (2002) Real estate development ( $2^{\text {nd }}$ edition). Capital University of Economics and Business Express, Beijing, P. R. China, 97 p.

Quan, D.C., Titman, S. (1999) Do real estate prices and stock prices move together? An international analysis. Real Estate Economics, 27(2), p. 183-207.

Stevenson, S., Murray, L. (1999) An examination of the inflation hedging ability of Irish real estate. Journal of Real Estate Portfolio Management, 5(1), p. 59-69.

Webb, J. R. (1990) On the exclusion of real estate from the market portfolio. Journal of Portfolio Management, fall, p. 78-84.

Webb, J. R., Sirmans, C. (1980) Yields and risk measures for real estate 1966-1977. Journal of Portfolio Management, fall, p. 14-19. 